Conference Paper

\title{
Biotechnology for Beginner Student
}

\author{
Elly Syafriani*, Medina Uli Alba Somala, Nova Triani
}

Study Program of Agrotechnology, Faculty of Agriculture, Universitas Pembangunan Nasional "Veteran" Jawa Timur, Surabaya, Indonesia

${ }^{*}$ Corresponding author:

E-mail:

ellysyafriani.agrotek@upnja-

tim.ac.id

\begin{abstract}
The research aims to produce a textbook for undergraduate students, especially the students of the Agrotechnology Study Program in Agricultural Faculty of UPN "Veteran" Jawa Timur. Since beginner students quite hard to understand the theory and practice of biotechnology in the agricultural field, thus a textbook was needed to help them improved their understanding of all the general and basic knowledge of biotechnology. This research was conducted by collecting any information from some literature due to biotechnology, then write it into a good textbook. Moreover, some of the research results were also reported in it. This textbook was included eight chapters, respectively: 1) definition, history, and the role of biotechnology; 2) genetic materials; 3) gene structure and expression; 4) molecular technique; 5) biotechnology application; 6) molecular marker and biomarker; 7) bioinformatic; and 8) security, management and intellectual property rights of the genetically modified organism. This book was also written completely with some questions as a task for the students in each chapter. As a result, a textbook with the specificity is 205 pages in HVS (A4) size, written in Bahasa, and the title of this book is "Bioteknologi Umum Untuk Mahasiswa Pemula (Teori dan Aplikasi Bioteknologi di Segala Bidang)". Although this book was aiming at agricultural students, the theory in it was also enriched with biotechnology information in some aspects, such as medical, environmental, and food technology.
\end{abstract}

Keywords:textbook, biotechnology, agricultural, molecular

\section{Introduction}

Biotechnology applications in all aspects of life have generally doing to increase people's welfare (Jamsari, 2007). A well-understanding of the basic knowledge of Biotechnology could encourage the utilization and the development of Biotechnology, especially for research. Biotechnology is a technology using a living organism or the part of the organism's body (DNA/ protein, cell, tissue, etc.) in resulting or in modifying a product for microbe, plant, and animal breedings (Nugroho \& Rahayu, 2018). In yielding students with an entrepreneurial spirit who use biotechnology in their business, a good understanding and mastery of biotechnology is a must.

Biotechnology is one of the subjects for the fourth-semester student of the Agrotechnology Study Program in Agricultural Faculty, UPN “Veteran” Jawa Timur. In the Biotechnology subject, the student will learn and need to understand anything in the Biotechnology scope. Biotechnology was known as a complex and advanced subject from some lessons such as biology, microbiology, chemistry, genetics, and others. Thus, to study Biotechnology, many students found it difficult to understand it. For students to understand biotechnology easily, learning facilities in the form of manuals or mandatory handbooks for students should be provided by the campus, especially lecturers who are experts in the field of biotechnology themselves.

The biotechnology textbook as the mandatory handbooks for fourth-semester students as the beginner student will lead them and become the instructional book which written by following 
the semester learning plan or "RPS" (Rencana Pembelajaran Semester). It is important to ensure that the contents of the textbook are in line with the "RPS" and the curriculum. Thus the lecturer and the institutional can reach the learning outcomes for the student in the same parameters with other universities who also have the Biotechnology subject. In the end, the textbook is not only helpful for the student, but also the lecturer and the institute. Practically, the content of the textbook is not only about biotechnology theory but also includes several questions in each chapter as an exercise for students.

The contents of the textbook in this research were divided into eight chapters. The first chapter explained the definition, history, and the role of biotechnology to make the student has a clear understanding of what biotechnology is. The second chapter briefly explained the genetic materials. The third is talked about the gene structure and its expression, so the student has wellknown that the gene structure is consists of a promoter, open reading frame (ORF), and terminator. Where the gene expression will not occur without the promoter, then the ORF will express as the amino acid (protein), and the terminator will stop the expression process. The fourth chapter described molecular techniques such as DNA isolation, Polymerase Chain Reaction (PCR), and gene cloning. The fifth chapter is about biotechnology application in some fields: medical, agricultural, food engineering, and environmental. The next chapter is about molecular markers and biomarker that helpful for the student if they have any interest to do identification research of a novel gene or due to finding a new molecular marker for a specific organism. Then the seventh chapter explained bioinformatics as a tool for the researcher to analyze the gene and to predict its function and also the 3D-modelling structure by using the online and offline software. The last chapter is about the security, management, and intellectual property rights of genetically modified organisms.

All the chapters are written by using the literature review and descriptive method. As this research aims to produce a textbook for undergraduate students, especially the students of the Agrotechnology Study Program in Agricultural Faculty of UPN “Veteran" Jawa Timur, thus the literature and descriptive methods are the suitable method to produce the textbook. This research used some journals and also some textbooks of Biotechnology as the literature. Either the information in the journals or the Biotechnology textbooks are used as the data of this research. The textbook in this research enriches with some tables and figures. Those will help the student to easily understand the theory.

\section{Methods}

This research was conducted by using the literature review and descriptive method. All the information in the textbook was collected from some literature and some results of the biotechnology research. Furthermore, the collected information was become the data in this research and written into a textbook. The data was explained in the descriptive and narrative text (paragraph).

\section{Results and Discussion}

The result of this research is a textbook with the specificity is 205 pages in HVS (A4) size, written in Bahasa and the title of the book is "Bioteknologi Umum Untuk Mahasiswa Pemula (Teori dan Aplikasi Bioteknologi di Segala Bidang). The cover layout of this book has shown in figure 1. 


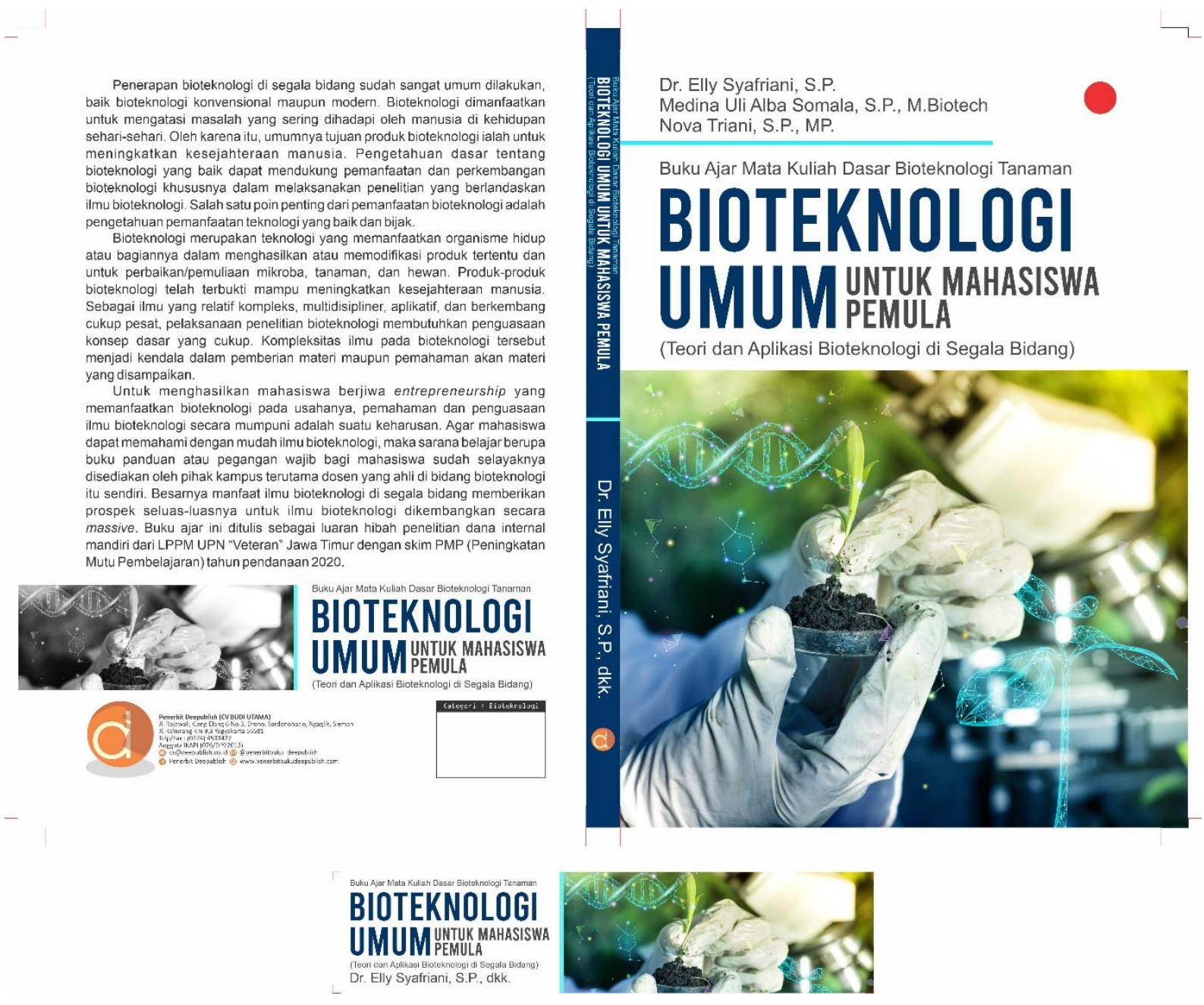

Figure 1. Cover layout of the book

The cover layout has designed by the "Deepublish" publisher that operated in Yogyakarta. It is one of the national publisher organization members, namely IKAPI (Ikatan Penerbit Indonesia), since 2012. Deepublish will publish the textbook of this research in November 2020.

\section{Brief of book's contents}

Chapter 1: Definition, history, and the role of biotechnology

The discovery of the fermentation process for making a beer and wine, and also to produce cheese has been present for a long time ago by using the living organism. The use of living organisms to process food and make other products useful for humankind is usually referred to as "biotechnology" (Keener et al., 2019). However, beginning in the 1980s, the word biotechnology has a new meaning. Nowadays, most people have a new definition of biotechnology as the manipulation of an organism's genes to create genetically modified organisms (GMO) (World Health Organization, 2005). In this chapter, readers will explore the development of biotechnology from its inception to the present, explain the science behind biotechnology, and help readers make informed judgments about the future role of biotechnology. 


\section{Chapter 2: Genetic materials}

DNA is the main genetic material in protein synthesis, so DNA serves as the basis for most genetic studies (Cooper, 2000). The genome is the total amount of genetic material (DNA) carried in the cell (Stengel \& Crespi, 2013). The basic unit of DNA structure is the nucleotide, consisting of a phosphate, a deoxyribose sugar, and a nitrogenous base (Cooper, 2000). Replication is the process of multiplying genetic material. Semiconservative, conservative and dispersive are the three DNA replication hypotheses (Alnaji, 2018). Transcription is the synthesis of RNA that completes one of the DNA strands. The translation is the process of translating the nucleotide sequence present in the mRNA molecule into a series of amino acids that make up proteins (Arayici et al., 2014). Proteins are polymers of amino acids (polypeptides) that have various functions (Khan, 2017).

\section{Chapter 3: Gene structure and expression}

The differences in the cell arrangement of prokaryotic and eukaryotic bodies also have an impact on the gene structure and genome organization in the two bodies. The composition of genes and the genome of eukaryotes is more complex than that of prokaryotes. The process of gene expression is related to the transcription and translation processes. There is a difference between the transcription process of prokaryotic bodies and eukaryotic bodies (Yuwono, 2005).

The transcription process is a process where one of the coding strands is doubled (coding strand/positive strand), by complementing the other threads as a template (template strand/negative strand). Transcription is the process of copying the genetic codes contained in the DNA sequence so that it becomes an RNA molecule. At the same time, the translation process is a process of translating the nucleotide sequences contained in the mRNA molecule to become a series of amino acids that make up a protein or a polypeptide. Several methods in regulating transcription factors are temporal regulation, regulation by ligand binding, regulation by isolation, regulation with post-translation modification, regulation by blocking, and regulation by suppression or silencing mechanisms (Arayici et al., 2014; Yuwono, 2005).

Control of the expression of a gene can occur by positive control mechanisms or by negative control mechanisms. The positive control mechanism is that a gene will be expressed if specific molecules act positively so that transcription and translation can occur so that the gene can be expressed. Meanwhile, the negative control mechanism, namely a gene will be expressed if there are molecules that act negatively, such as pressing it so that it has an impact on the transcription and translation processes which affect the expression of the gene (Arayici et al., 2014, Yuwono, 2005).

\section{Chapter 4: Molecular technique}

Three molecular engineering skills that every student should have from this chapter are DNA isolation, PCR, and gene cloning. DNA isolation is the liberation of genetic material from the cell nucleus in the cytoplasm and histone protein bonds by striving to minimize the degree of mechanical and physical damage to the genetic material. In DNA isolation, there are three main principle steps in DNA isolation, namely: 1) Breaking the cell wall; 2) DNA deproteinization or purification (purification of DNA from proteins); and 3) DNA harvesting (DNA precipitation). The breaking of the cell wall can be done mechanically or chemically (Jamsari, 2007). The results of DNA isolation can be checked using electrophoresis techniques (Lee et al., 2012). PCR as an in vitro DNA propagation technique can be performed to isolate and provide sufficient target DNA stock for cloning and other genetic engineering processes. PCR supporting components in addition to the PCR machine technology itself, several other important materials are also needed, such as DNA template, DNA polymerase enzymes, and primers (Atawodi et al., 2011). Amplicon or PCR results have been obtained, which can be further to the stage of gene cloning. Gene cloning is the multiplication or duplication of DNA in host cells through the help of vectors in the form of 
plasmids (Padmanabhan et al., 2011). In general, the method used in the gene cloning process is genetic transformation by heat shock, where cloning indicators can be observed in the blue-white selection method and colony PCR (Padmanabhan et al., 2011; Singh et al., 2010).

\section{Chapter 5: Biotechnology application}

The mutation is a sudden and random change in a gene that results in phenotypic and genotypic changes that can be passed on to the offspring from one generation to the next. Mutations can occur spontaneously and induction, as well as at the gene and chromosome level. Identified and classified mutations indicate that the types of mutations are diverse. It depends on the type of nucleotide or chromosomal alteration, the mutation effect in the target organism, and others. In general, the effects of mutations are detrimental. But in certain instances, mutations are known for some beneficial effects, especially for the plants to yield new high yielding varieties. Since the plant breeders use this beneficial effect, then it is known as mutation breeding (Pathirana, 2011; Oladosu et al., 2016). The successful experiment of plant breeding so interacts with the tissue culture. The combination of the two is known to make it easier to obtain new superior varieties, especially through somaclonal variations. Where the active plant cell divides such as callus has a high chance of successful mutation. Through mutation techniques and other genetic modification techniques (genetic engineering), the application of biotechnology is known to have major benefits or roles in all aspects of life, especially medical, agriculture, food engineering, and the environment (Gupta et al., 2016).

\section{Chapter 6: Molecular marker and biomarker}

Molecular markers and biomarkers are several methods or techniques that can be used to detect and study important characters in living things (Jamsari, 2013). Along with the times and technology, molecular markers and biomarkers have progressed very rapidly. From an effortless technique, low cost, but the results are less accurate. In the current time, several types of molecular markers and biomarkers have been developed which products are more accurate, efficient, and effective even though the costs required are relatively high. In the end, the selection of molecular markers and biomarkers to be used is adjusted to the type of sample (whether DNA or protein), the appropriate technology for the kind of sample used (PCR-based or a combination of PCR and restriction, etc.), and the intended purpose of the researcher (Avise, 1994; Batovska et al., 2009).

\section{Chapter 7: Bioinformatic}

Bioinformatics is both a science and a tool that helps facilitate the management and analysis of genetic information from all organisms in the world (Edwards et al., 2009). Several databases, software, online and offline programs are designed and developed for the management and analysis of this genetic information. The most commonly used database is the NCBI (National Center for Biotechnology Information) based in the United States. Apart from storing genetic information, the NCBI database is equipped with other services that can be used to analyze the gene sequences under study. Such as the; BLAST program, Open Reading Frame finder, etc. as well as the provision of various kinds of journals and books online. BioEdit is one of the most DNA sequence analysis tools to use for its accessible and free-downloaded reasons (Alzohair, 2011). All the bioinformatics analysis was built based on the sequence alignment method which is useful to construct an evolution through a phylogenetic tree (Tamura et al., 2013), detecting a sequence motif (Marcler-Bauer et al., 2012), determining the 3D structure of sequences (Kelleyy et al., 2015), explaining the cell rules, determining the protein function and metabolism preparing, DNA fragments arranging (Altman et al., 2013), and also utilization of scripting languages. 
Chapter 8: Security, management and intellectual property rights of the genetically modified organism

Genetically modified products are organisms that had a genetic structure alteration due to the treatment of modern biotechnology. Thus, these organisms are different from their natural organism (Udriste \& Badulescu, 2017). In general, genetically modified organisms have the advantage of having different genetic structures compared to their ancient ones. Based on PP No. 21/2005 states that genetically engineered products originating from within and outside the country to be studied/tested for release or distribution must be accompanied by information on environmental safety, food safety, and feed safety. Information regarding environmental safety includes description and purpose of use, genetic and phenotypic changes to be detected, taxonomic identity, physiology and reproduction, the evident organisms as the gene source, valid genetic modified methods, the evident molecular characterization, stable gene expression, and means of destruction.

Genetically modified products are regulated in legislation both under international law (Udriste \& Badulescu, 2017; Strauss, 2006) and applicable law in Indonesia. The safety of genetically modified products in Indonesia has been regulated quite well because it is following the Convention on Biological Diversity and the Cartagena Protocol. Legislation has been passed from the statutory level to the level of the decision of the head of BPOM. Based on PP No. 21 of 2005 article 29 concerning the Biosafety of Genetically Engineered Products, then formed three institutions, namely the Genetically Modified Products Biosafety Commission, the Genetically Modified Products Biosafety Clearing House, and the Genetically Modified Products Biosafety Technical Team. Genetically modified plants that involve Patents can protect the use of microbiological processes, namely Article 7 of the Patent Law and protection of plant varieties as regulated in the Law on Plant Variety Protection Article 11 paragraph 4. Patent rights are granted for technology in producing plant variety assembly.

\section{Conclusion}

Based on this research, we can conclude that a textbook of "Bioteknologi Umum Untuk Mahasiswa Pemula (Teori dan Aplikasi Bioteknologi di Segala Bidang)" has been produced successfully and ready to use for the beginner student to help them improved their understanding of the general and basic knowledge of biotechnology.

\section{Acknowledgment}

We would like to thank LPPM UPN "Veteran" Jawa Timur for fully funding of this research through PMP (Peningkatan Mutu Pembelajaran) program with the contract number: SPP/38/UN.63.8/LT/V/2020.

\section{References}

Alnaji, H. (2018). DNA replication (In book: Introduction to Molecular Biology for Undergraduates; pp.20-28). Edition: 1st Chapter: 4. Available from: https://researchgate.net/publication/329323298 DNA Replication.

Altman, T., Travers, M., Kothari, A., Caspi, R., \& Karp, P.D. (2013). A systematic comparison of the MetaCyc and KEGG pathway database. BMC Bioinformatics, 14, 112.

Alzohair, A.M. (2011). BioEdit: An important software for molecular biology. GERF Bulletin of Biosciences, $2(1), 60-61$.

Arayici, P. P., Acar, T., \& Karahan, M. (2014). Transcription and translation (In book: applications of molecular genetics in personalized medicine; Publisher: OMICS International Available https://researchgate.net/publication/325827703 Transcription and translation.

Atawodi, S.E., Atawodi, J.C., \& Dzikwi, A. A. (2011). Polymerase chain reaction: Theory, practice and application: A Review. Sahel Medical Journal, 13(2), 113-119. doi: 10.4314/smj2.v13i2.64834.

Avise, J.C. (1994). Molecular markers, natural history, and evolution (Second Edition). Sinauer Associates, Inc. Publisher. Massachuttes. 
Batovska, D. I., Todorova, I. T., Parushev, S.P., Nedelcheva, D.V., Bankova, V. S., Popov, S. S., Ivanova, I. I., \& Batovski, S. A. (2009). Biomarkers for the prediction of the resistance and susceptibility of grapevine leaves to downy mildew. Journal of Plant Physiology, 166(7), 78-785, doi: 10.1016/j.jplph.2008.08.008

Cooper, G. M. (2000). The cell: A molecular approach. 2nd edition. Sunderland (MA): Sinauer Associates. Available from: https://www.ncbi.nih.gov/books/NBK9944/.

Edwards, D., Stajich, J., \& Hansen, D. (2009). Bioinformatics: tool and aplication. springer science \& business media.

Gupta, V., Sengupta, M., Prakash, J., \& Tripathy, B.C. (2016). An introduction to biotechnology. Basic and Applied Aspects of Biotechnology, $1-21$.

Jamsari. (2007). Bioteknologi pemula: Prinsip dasar dan aplikasi analisis molekuler. Unri Press, Pekanbaru.

Jamsari. (2013). Rekayasa Genetika (untuk analisis genom dan produksi organisme transgenik). Pekanbaru: UNRI Press.

Keener, K., Hoban, T., \& Balasubramanian, R. (2019). Biotechnology and its applications. NC State University.

Kelleyy, L.A., Mezulis, S., Yates, C. M., Wass, M. N., \& Sternberg, M. J. (2015). The Phyre2 web portal for protein modelling. prediction and analysis. Nature Protocols, 10(6), 845-858.

Khan, R. H. (2017). Protein structure and function. Austin publishing group. Available from: https://researchgate.net/publication/316139245_Protein_Structure_and_Function.

Lee, P. Y., Costumbrado, J., Hsu, C. Y., \& Kim, Y. H. (2012). Agarose gel electrophoresis for the separation of DNA Fragments. Journal of Visualized Experiment, 20(62), 3923, doi: 10.3791/3923.

Marcler-Bauer, A., Zheng, C., Chitsaz, F., Derbyshire, M.K., Geer, L.Y., Geer, R.C., Gonzales, N. R., Gwadz, M., Hurwitz, D. I., Lanczycki, C. J., Lu, F., Lu, S., Marchler, G. H., Song, J. S., Thanki, N., Yamashita, R. A., Zhang, D., \& Bryant, S. H. (2012). CDD: Conserved Domains and Protein Three-Dimensional Structure. Nucleic Acids Research, 41(D1): D348-D352. doi: 10.1093/nar/gks1243.

Nugroho, E. D., \& Rahayu, D. A. (2018). Pengantar bioteknologi. Deepublish, Yogyakarta.

Oladosu, Y., Rafii, M. Y., Abdullah, N., Hussin, G., Ramli, A., Rahim, H. A., Miah, G., \& Usman, M. (2016). Principle and application of plant mutagenesis in crop improvement: A Review; Biotechnology \& Biotechnology Equipment,30(1),1-16. https://doi.org/10.1080/13102818.2015.1087333

Padmanabhan, S., Banerjee, S., \& Mandi, N. (2011). Screening of bacterial recombinants: Strategies and preventing false positives. Molecular Cloning-Seleted Applications in Medicine and Biology, p1-19.

Pathirana, R. (2011). Plant mutation breeding in agriculture. CAB Reviews Perspective in Agriculture Veterinary Science Nutrition and Natural Resources, 6(032), 1-20. DOI: 10.1079/PAVSNNR20116032

Singh, M., Yadav, A. S., Ma, X., \& Amoah, E. A. (2010). Plasmid DNA transformation in Escherichia coli: Effect of heat shock temperature, duration, and cold incubation of $\mathrm{CaCl} 2$ treated cells. International Journal of Biotechnology and Biochemistry, 6(4), 561-568.

Stengel, A., \& Crespi, B. (2013). What is a genom?. Molecular Ecology, 22, 3437-3443.

Strauss, D.M. (2006). The international regulation of genetically modified organisms: Importing caution into the U.S.Food Supply. Business Facult Publications. 221.

Tamura, K., Stecher, G., Peterson, D., Filipski, A., \& Kumar, S. (2013). Mega 6: Molecular evolutionary genetics analysis version 6.0. Molecular Biology and Evolution, 30(12), 2725-2729.

Udriste, A. A., \& Badulescu, L. (2017). Genetically modified organisms. Research Journal of Agricultural Science, 49(4).

World Health Organization. (2005). Modern food biotechnology, human health, and development: An evidence-based study. World Health Organization.

Yuwono, T. (2005). Biologi molekular. Erlangga, Jakarta. 